\title{
Swedish Technology Teachers’ Attitudes to their Subject and its Teaching
}

\author{
Charlotta Nordlöf, Gunnar Höst and Jonas Hallström \\ Journal Article
}

\section{Tweet}

N.B.: When citing this work, cite the original article.

This is a postprint version of an article published in:

Charlotta Nordlöf, Gunnar Höst and Jonas Hallström, Swedish Technology Teachers’ Attitudes to their Subject and its Teaching, Research in Science \&amp; Technological Education, 2017. pp.1-20.

Research in Science \&amp; Technological Education is available online at informaworldTM: http://dx.doi.org/10.1080/02635143.2017.1295368

Copyright: Taylor \& Francis (Routledge): SSH Titles http://www.routledge.com/

Postprint available at: Linköping University Electronic Press

http://urn.kb.se/resolve?urn=urn:nbn:se:liu:diva-135311

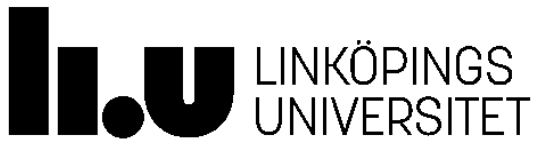




\title{
Swedish Technology Teachers’ Attitudes to their Subject and its Teaching
}

\section{Charlotta Nordlöf *}

Department of Social and Welfare Studies, Linkoping University, Norrköping, Sweden

Linköping University, Department of Social and Welfare Studies, 60174 Norrköping, Sweden. Email: charlotta.nordlof@liu.se, Phone: +4611363026

\author{
Gunnar Höst
}

Department of Science and Technology, Linkoping University, Norrköping, Sweden

Linköping University, Department of Science and Technology, 60174 Norrköping, Sweden. Email: gunnar.host@liu.se, Phone: +46 11363362

\section{Jonas Hallström}

Department of Social and Welfare Studies, Linkoping University, Norrköping, Sweden Linköping University, Department of Social and Welfare Studies, 60174 Norrköping, Sweden. Email: jonas.hallstrom@liu.se, Phone: +4611 363041 


\section{Swedish Technology Teachers’ Attitudes to their Subject and its Teaching}

Background:

From previous research among science teachers it is known that teachers' attitudes to their subjects affect important aspects of their teaching, including their confidence and the amount of time they spend teaching the subject. In contrast, less is known about technology teachers' attitudes.

Purpose:

Therefore, the aim of this study is to investigate Swedish technology teachers' attitudes toward their subject, and how these attitudes may be related to background variables.

Sample:

Technology teachers in Swedish compulsory schools $(n=1153)$ responded to a questionnaire about teachers’ attitudes, experiences, and background.

Methods:

Exploratory factor analysis was used to investigate attitude dimensions of the questionnaire. Groupings of teachers based on attitudes were identified through cluster analysis, and multinomial logistic regression was performed to investigate the role of teachers' background variables as predictors for cluster belonging.

Results:

Four attitudinal dimensions were identified in the questionnaire, corresponding to distinct components of attitudes. Three teacher clusters were identified among the respondents characterized by positive, negative, and mixed attitudes toward the subject of technology and its teaching, respectively. The most influential predictors of cluster membership were to be qualified for teaching technology, having participated in in-service-training, teaching at a school with a proper overall teaching plan for the subject of technology and teaching at a school with a defined number of teaching hours for the subject. 


\section{Conclusions:}

The results suggest that efforts to increase technology teachers' qualifications and establishing a fixed number of teaching hours and an overall teaching plan for the subject of technology may yield more positive attitudes among teachers toward technology teaching. In turn, this could improve the status of the subject as well as students' learning.

Keywords: attitudes; technology education; technology teachers 


\section{Introduction}

Teachers' attitudes play a central part in managing science and technology teaching, with all its complexities, both inside and outside the classroom. From research in science education it is known that teachers' attitudes to their subjects affect their teaching in several areas (Osborne, Simon, and Collins 2003; van Aalderen-Smeets and Walma van der Molen 2013). Less positive attitudes are found among teachers with, for example, lower self-efficacy and confidence. Negative attitudes are also associated with less time spent on teaching the subject and discussing it in the classroom. Such teachers also tend to prefer standardized methods and top-down instructions. Furthermore, science teachers with less positive attitudes seem to be poorer at encouraging the students’ own attitudes toward science (Holroyd and Harlen 1996; van Aalderen-Smeets and Walma van der Molen 2013).

Attitude can be defined as 'a psychological tendency to evaluate an object in terms of favorable or unfavorable attribute dimensions such as good/bad or positive/negative’ (van Aalderen-Smeets, Walma van der Molen, and Asma 2012, 161). Attitudes are often separated into three parts: cognition, affect, and behavior. This division informs a theoretical framework for primary teachers' attitudes toward science in general and the teaching of science, developed by van Aalderen-Smeets, Walma van der Molen, and Asma (2012). In this framework, attitudes consist of three components: Cognitive beliefs, which concerns the relevance of teaching science and the perceived difficulty of teaching science; Affective states, including positive and negative feelings such as enjoyment and anxiety of teaching science; and Perceived control, concerning feelings of difficulties in teaching science related to internal and external factors such as self-efficacy and context dependency (van AalderenSmeets, Walma van der Molen, and Asma 2012; van Aalderen-Smeets and Walma van der Molen 2013; cf. Rohaan, Taconis, and Jochems 2012). In the present study, this attitude 
model will be applied to technology education to understand and analyse technology teachers' attitudes to their subject.

Previous research on how technology teachers view their subject has focused on the implementation of the technology curriculum (e.g. Jones and Carr 1992; Jones, Harlow, and Cowie 2004). Other studies have investigated teachers’ concept of and attitudes toward technology (e.g. De Vries 1991). The perceived importance of the technology subject, which can be considered to be an aspect of cognitive belief, has been examined in New Zealand in a study by Almutairi (2009), indicating that technology teachers themselves find the subject of technology to be important. However, technology is considered to be a low status subject by headmasters and teachers in other subjects according to Swedish studies (Nordlander 2011; Skolinspektionen 2014). A study by the Swedish National Agency for Education (Skolverket 2013) indicated that a vast majority (97 \%) of teachers in general, including technology teachers, consider themselves to have good enough subject knowledge, which can be considered to be an aspect of perceived control. A lack of confidence in technology teaching may nevertheless be a problem, related to the affective state component of teachers' attitudes. Holroyd and Harlen (1996) point out that a lack of confidence and understanding influence how teachers teach: 'Teachers may compensate for doing less of a low-confidence aspect by doing more of a higher-confidence aspect; in practice this can mean [...] spending more time on construction work in technology and less on design’ (Holroyd and Harlen 1996, 334).

Despite the established importance of teachers' attitudes in relation to teaching, the literature review above indicates that teachers' attitudes is still a rather unexplored area in technology education. The present study will therefore focus on teachers' views of and attitudes to technology teaching in response to this identified need for more research. 


\section{Aim}

The aim of this study is to investigate Swedish technology teachers' attitudes toward their subject, and how these attitudes may be related to background variables. The aim is addressed by responding to the following research questions:

(1) What are Swedish technology teachers' attitudes to the subject of technology and its teaching?

(2) What are the possible explanations for their different attitudes?

\section{Methods}

\section{Educational context, Participants and Data Collection}

Technology is a mandatory, standalone subject in the Swedish compulsory school but shares teaching time with chemistry, physics, and biology, which means that the amount of teaching hours in technology varies among schools. The current technology curriculum was introduced in 2011 and its core content includes three areas: Technological solutions, Working methods for developing technological solutions, and Technology, man, society and environment. Specific core content is defined for grades 1-3, 4-6, and 7-9. For example, the area Technological solutions contains common materials and mechanisms with a focus on everyday life (1-3); electrical circuits and simple technological systems (4-6); and basic electronics, control systems, manufacturing and properties of materials (7-9) (Skolverket, 2011). Technology education thus mainly focuses on technological literacy and includes both practical and theoretical components. According to a report from the Swedish Schools Inspectorate (Skolinspektionen, 2014), however, teachers generally devote too much time to designing and constructing with their students, and too little time to reflection and consideration of contextual aspects of technology. 
The target population for this study was Swedish teachers who teach technology at levels ranging from preschool class (6 years old) to ninth grade (16 years old), which included approximately 16000 teachers (Skolverket, 2016). An invitation to participate in a web-based inquiry was sent to 4000 teachers, of which 1367 completed the questionnaire. Of these, 214 individuals were excluded since they had not taught technology, giving a total number of 1153 participants (79.5\% female and 20.5\% male) from 234 of 290 Swedish municipalities. Teachers from school levels across the Swedish compulsory school (from preschool class to ninth grade) participated, but most responding teachers taught grades 4-6, that is students 10 to 12 years old. The distribution of respondents does not reflect where most technology education is carried out, however, because it is actually decided by the schools themselves and most common is to have the lion's share of technology in grades 7-9.

Approximately half of the participants (51.3\%) confirmed that they were qualified to teach technology according to the current rules at the time of data collection in 2012. To be qualified to teach technology, teacher training in technology was required.

Data were collected by the survey company Demoskop in April 2012 through a web-based questionnaire. The questionnaire was constructed by CETIS (Centre for School Technology Education), a center commissioned by the government to develop technology education in Sweden, in collaboration with 'Teknikföretagen', a Swedish industrial employers' organization that represents 3600 technology companies. The latter has as one of its commitments to bring more young people in Sweden to study technology in tertiary education, which is why it has an interest in technology education in compulsory school. Aspects of the results with respect to the situation for compulsory school technology education was published in a report (Teknikföretagen 2012). The questionnaire were developed by CETIS during three iterations of enquiry between 1998 and 2009. 
The questionnaire consisted of teacher background questions, school context questions and attitude items. The full questionnaire consisted of 21 closed items and one open item. Some closed items contained one or more follow-up questions, yielding a maximum of 46 questionnaire items in total. The present study uses 32 closed questionnaire items. For 10 of these, participants responded by selecting among a number of defined options (e.g. yes/no, male/female), while 22 required respondents to rate their agreement to a statement on a Likert-type scale ranging from 1 to 6 . The scale represented opposites, where 1 corresponded to a disagreement with the statement (e.g. 'Do not agree at all') and 6 corresponded to agreement (e.g. 'Totally agree').

\section{Data Analysis}

\section{Analytical overview}

Responding to the research questions prompted us to employ a quantitative approach wherein statistical methods were applied in three steps. First, exploratory factor analysis was used to examine the underlying structure of teachers' responses to the attitude items. This step involved revealing relations between items and forming corresponding factors that reflect aspects of underlying attitudes in the items. Second, cluster analysis was employed to identify groupings of teachers based on their attitudes. This method discerns clusters of teachers that have similar patterns of attitudes, as revealed by the scores on the factors identified in the factor analysis. Third, relations between teachers' attitudes and their backgrounds and teaching contexts were explored through multinomial logistic regression, wherein cluster membership was predicted based on teachers' responses to background variables. SPSS 22 was used to analyse the study data. 


\section{Factor Analysis}

Exploratory factor analysis was conducted with 17 questionnaire items that were related to teachers' attitudes (Fig 1). The decision to use factor analysis was supported by the KaiserMeyer-Olkin Measure of Sampling Adequacy $(\mathrm{KMO})=0.83$ (Beavers et al. 2013) and Bartlett's test of Sphericity $(\mathrm{p}<.001)$, which indicated that factor analysis was appropriate for the data (Dziuban and Shirkey 1974). Correlations were found to be larger than 0.30, further supporting factor analysis (Tabachnick and Fidell 2014). Factor analysis was conducted through Principal Component Analysis (PCA) of the correlation matrix and Oblimin rotation.

\section{How satisfied are you overall with the way technology education is managed in your school?}

$\begin{array}{llllllll}\text { Very dissatisfied } & 1 & 2 & 3 & 4 & 5 & 6 \text { Very satisfied Don't know }\end{array}$

Here are some statements about the subject of technology, how well does this agree with your opinion?



2. It is a good thing that technology is compulsory throughout school

3. Technology is an important subject

4. The management of my school wants to develop the subject of technology

5. The subject of technology will have increased importance in the future

6. Knowledge of technology is generally important for the students and their future

How important are the following factors for how you teach technology?

$\begin{array}{llllllll}\text { No importance at all } & 1 & 2 & 3 & 4 & 5 & 6 \text { Very important } & \text { Don't know }\end{array}$

7. My own interest/knowledge of various technology fields

8. The core content of the curriculum

9. At my school there are well-established work fields in technology

How well do the following statements agree with your opinion?

$\begin{array}{llllllll}\text { Doesn't agree at all } & 1 & 2 & 3 & 4 & 5 & 6 \text { Completely agree Don't know }\end{array}$

10. At my school, we have plenty of good teaching material for technology education

11. It can be difficult to have enough time to teach technology

12. I think the curriculum core content is a good starting point for teaching

13. The knowledge requirements are clear

14. I have the necessary training to conduct good technology education

15. I feel confident in teaching technology

16. I get sufficient time for developing my teaching

17. I am passionate about the subject of technology

Figure 1. Statements from the inquiry, as used in the factor analysis. 
One construct ('It can be difficult to get enough time to teach technology') was removed after the first round of analysis since it showed loadings of less than 0.4 and a low communality (Pett, Lackey, and Sullivan 2003). The remaining 16 constructs were kept since they showed high communalities.

The number of factors to retain was decided based on multiple methods, as recommended in the literature (Henson and Roberts 2006; O’connor 2000). All methods used - the Eigenvalue $>1$ rule, Screeplot analysis, Parallel analysis and Velicer's minimum average partial (MAP) test - supported a four-factor solution as the most appropriate.

Factors were interpreted based on the Oblimin rotation, since the Component Correlation Matrix showed correlations between factors 1 and 3 (0.328), and 1 and 4 (-0.307) (Pett, Lackey, and Sullivan 2003). The Pattern matrix and Structure matrix are shown in Table 1.

\section{Cluster analysis}

Cluster analysis using teachers' factor scores as data was conducted in two steps. An initial hierarchical cluster analysis was performed to find out the most appropriate number of clusters, followed by a K-mean cluster analysis to find the cluster solution (Clatworthy et al. 2005; Hair et al. 2010; Mooi and Sarstedt 2011).

Hierarchical clustering. A selection of different types of hierarchical methods and similarity measures indicated similar solutions containing two, three or five clusters of approximately equal sizes, providing a validation of stability (Mooi and Sarstedt 2011).

Ward's method was employed to further investigate the appropriate number of clusters, using the Squared Euclidean distance, as recommended (Hair et al. 2010). Inspection of the agglomeration schedule (Fig. 2) (Clatworthy et al. 2005) indicated a large 
Table 1. Structure Matrix, Pattern Matrix and communalities.

\begin{tabular}{|c|c|c|c|c|c|c|c|c|c|}
\hline & \multicolumn{4}{|c|}{ Structure coefficients } & \multicolumn{4}{|c|}{ Pattern coefficients } & \multirow{2}{*}{$\begin{array}{c}\begin{array}{c}\text { Commu- } \\
\text { nalities }\end{array} \\
h^{2}\end{array}$} \\
\hline & $\begin{array}{c}\text { Component } \\
1\end{array}$ & $\begin{array}{c}\text { Component } \\
2\end{array}$ & $\begin{array}{c}\text { Component } \\
3\end{array}$ & $\begin{array}{c}\text { Component } \\
4\end{array}$ & $\begin{array}{c}\text { Component } \\
1\end{array}$ & $\begin{array}{c}\text { Component } \\
2\end{array}$ & $\begin{array}{c}\text { Component } \\
3\end{array}$ & $\begin{array}{c}\text { Component } \\
4\end{array}$ & \\
\hline $\begin{array}{l}\text { Technology is an important } \\
\text { subject }\end{array}$ & 0.89 & 0.19 & 0.326 & -0.354 & 0.856 & 0.013 & 0.018 & -0.083 & 0.8 \\
\hline $\begin{array}{l}\text { It is a good thing that } \\
\text { technology is compulsory } \\
\text { throughout school }\end{array}$ & 0.839 & 0.189 & 0.33 & -0.374 & 0.789 & 0.011 & 0.035 & -0.119 & 0.72 \\
\hline $\begin{array}{l}\text { Knowledge of technology } \\
\text { is generally important for } \\
\text { the students and their } \\
\text { future }\end{array}$ & 0.839 & 0.152 & 0.351 & -0.342 & 0.794 & -0.027 & 0.073 & -0.084 & 0.716 \\
\hline $\begin{array}{l}\text { The subject of technology } \\
\text { will have increased } \\
\text { importance in the future }\end{array}$ & 0.811 & 0.199 & 0.256 & -0.189 & 0.825 & 0.072 & -0.009 & 0.079 & 0.666 \\
\hline $\begin{array}{l}\text { At my school, we have } \\
\text { plenty of good teaching } \\
\text { material for technology } \\
\text { education }\end{array}$ & 0.148 & 0.78 & 0.189 & -0.225 & -0.004 & 0.77 & 0.004 & -0.04 & 0.61 \\
\hline $\begin{array}{l}\text { How satisfied are you } \\
\text { overall with the way } \\
\text { technology education is } \\
\text { managed in your school? }\end{array}$ & 0.137 & 0.734 & 0.202 & -0.284 & -0.033 & 0.707 & 0.019 & -0.119 & 0.552 \\
\hline $\begin{array}{l}\text { At my school there are } \\
\text { well-established work } \\
\text { fields in technology }\end{array}$ & 0.099 & 0.73 & 0.128 & -0.115 & -0.011 & 0.75 & -0.023 & 0.055 & 0.537 \\
\hline $\begin{array}{l}\text { I get sufficient time for } \\
\text { developing my teaching }\end{array}$ & 0.142 & 0.616 & 0.211 & $\underline{-0.464}$ & -0.067 & 0.541 & 0.013 & -0.352 & 0.49 \\
\hline $\begin{array}{l}\text { The management of my } \\
\text { school wants to develop } \\
\text { the subject of technology }\end{array}$ & 0.375 & 0.58 & 0.248 & -0.079 & 0.305 & 0.549 & 0.07 & 0.166 & 0.437 \\
\hline $\begin{array}{l}\text { I think the curriculum core } \\
\text { content is a good starting } \\
\text { point for teaching }\end{array}$ & 0.272 & 0.166 & 0.902 & -0.239 & -0.023 & -0.038 & 0.919 & 0.002 & 0.816 \\
\hline $\begin{array}{l}\text { The knowledge } \\
\text { requirements are clear }\end{array}$ & 0.257 & 0.212 & 0.8 & -0.215 & -0.007 & 0.037 & 0.798 & 0.015 & 0.641 \\
\hline $\begin{array}{l}\text { The core content of the } \\
\text { curriculum }\end{array}$ & 0.267 & 0.149 & 0.771 & -0.228 & 0.015 & -0.032 & 0.769 & -0.016 & 0.595 \\
\hline $\begin{array}{l}\text { I feel confident in teaching } \\
\text { technology }\end{array}$ & 0.28 & 0.35 & 0.319 & -0.889 & -0.025 & 0.138 & 0.059 & -0.848 & 0.814 \\
\hline $\begin{array}{l}\text { I have the necessary } \\
\text { training to conduct good } \\
\text { technology education }\end{array}$ & 0.198 & 0.326 & 0.312 & -0.855 & -0.109 & 0.126 & 0.085 & -0.835 & 0.76 \\
\hline $\begin{array}{l}\text { I am passionate about the } \\
\text { subject of technology }\end{array}$ & $\underline{0.525}$ & 0.235 & 0.316 & -0.793 & 0.304 & 0.01 & 0.02 & -0.692 & 0.717 \\
\hline $\begin{array}{l}\text { My own } \\
\text { interest/knowledge } \\
\text { concerning various } \\
\text { technology fields }\end{array}$ & 0.369 & 0.03 & 0.188 & -0.537 & 0.24 & -0.131 & 0 & -0.495 & 0.35 \\
\hline
\end{tabular}


Similarity measure coefficient

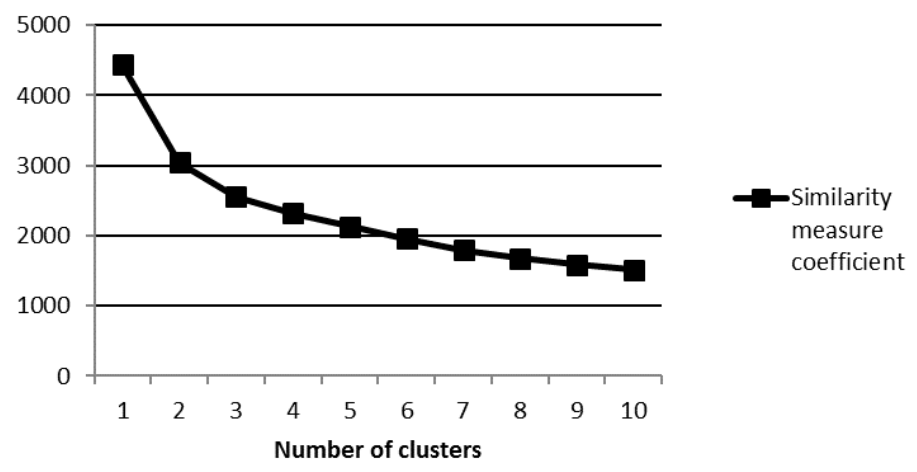

Figure 2. Plot of similarity measure coefficient and number of clusters.

jump between two and one clusters, a fairly big jump between three and two, and minor jumps between further clusters. The large jump between two and one clusters is not a dependable indicator, since the combination of the final two large clusters is expected to yield this behavior (Mooi and Sarstedt 2011).

Cluster analyses with forced solutions of three, four and five clusters were created and compared. The three-cluster solution was the most appropriate given that it resulted in interpretable clusters and that the other solutions contained unbalanced cluster sizes.

K-mean cluster analysis. The K-mean cluster analysis was performed with the final threecluster solution from the hierarchical clustering analysis (Table 2) as initial cluster centres. Final cluster centres, and the number of cases, are presented in Tables 3 and 4, respectively. Only slight differences between the initial (Table 2) and final (Table 3) cluster centres were found.

K-mean clustering was conducted on a subset of the data produced by splitting the dataset into randomized halves (Table 5). The final cluster centroids of the randomized half 
and the complete dataset were very similar, indicating stability (Clatworthy et al. 2005; Mooi and Sarstedt 2011) and validity of the clusters. The analysis of variance was statistically significant at the $\mathrm{p}<.01$ level (Table 6), further supporting differences between clusters for each of the four factors.

Table 2. Initial cluster centres for K-mean clustering for the whole dataset, based on the final cluster centres from hierarchical clustering.

\begin{tabular}{lccc}
\hline \multicolumn{4}{c}{ Initial Cluster Centres } \\
& 1 & 2 & 3 \\
& 4.38 & 5.64 & 5.39 \\
Factor 1 mean & 2.50 & 3.52 & 2.74 \\
Factor 2 mean & 2.54 . & \\
Factor 3 mean & 3.91 & 5.08 & 4.98 \\
Factor 4 mean & 2.83 & 5.10 & 3.77 \\
\hline
\end{tabular}

Table 3. Final cluster centres from K-mean clustering for the whole dataset.

\begin{tabular}{lcccc}
\hline \multicolumn{5}{c}{ Final Cluster Centres } \\
& 1 & 2 & 3 & Total mean \\
& 4.24 & 5.64 & 5.48 & 5.21 \\
Factor 1 mean & 2.36 & 3.74 & 2.73 & 3.00 \\
Factor 2 mean & 2.79 & 5.15 & 4.96 & 4.72 \\
Factor 3 mean & 3.90 & 5.18 & 3.79 & 4.07 \\
Factor 4 mean & 2.90 & & & \\
\hline
\end{tabular}

Table 4. Number of cases in each cluster in the final cluster solution.

\begin{tabular}{lrrl}
\hline & $\begin{array}{r}\text { Number of } \\
\text { cases }\end{array}$ \\
\hline Cluster & 1 & 296 & $26 \%$ \\
& 2 & 419 & $37 \%$ \\
& 3 & 423 & $37 \%$ \\
Valid & & 1138 & \\
Missing & & 15 & \\
\hline
\end{tabular}




\section{Multinomial Logistic Regression}

Multinomial logistic regression (Field 2009) was conducted with cluster membership as the dependent variable using ‘the Positive’ cluster as the reference (see Results section).

Teachers' responses to questionnaire items regarding their backgrounds, school conditions, and perceived influences on their technology teaching were used as predictors in the analysis (Table 7). The predictors included categorical as well as continuous variables.

Table 5. Final cluster centres of half the dataset.

\begin{tabular}{lcccc}
\hline \multicolumn{5}{c}{ Cinal Cluster Centres } \\
& 1 & 2 & 3 & Total mean \\
& 4.24 & 5.57 & 5.50 & 5.21 \\
Factor 1 mean & 2.50 & 3.85 & 2.59 & 3.00 \\
Factor 2 mean & 3.76 & 5.13 & 4.97 & 4.72 \\
Factor 3 mean & & & & \\
Factor 4 mean & 2.82 & 5.10 & 3.84 & 4.07 \\
\hline
\end{tabular}

Table 6. ANOVA of final cluster solution.

\begin{tabular}{lccccccc}
\hline \multicolumn{7}{c}{ ANOVA } \\
& Cluster & \multicolumn{7}{c}{ Error } \\
& Mean Square & df & Mean Square & df & $F$ & Sig. \\
& 193.4 & 2 & .426 & 1135 & 453.6 & .000 \\
Factor 1 mean & 189.0 & 2 & .587 & 1135 & 322.1 & .000 \\
Factor 2 mean & 179.6 & 2 & .593 & 1135 & 302.8 & .000 \\
Factor 3 mean & 476.2 & 2 & .479 & 1135 & 994.6 & .000 \\
Factor 4 mean & & & & & & \\
\hline
\end{tabular}


Table 7. Variables used as predictors in Multinomial Logistic Regression.

\section{Continuous Variables}

\section{Categorical Variables}

Variables of the teachers' backgrounds
Variables of the school context

Is there an overall planning, based on the new curriculum Lgr 11, for the subject of technology in your school?

How is technology generally taught in your school today?

Are you teaching ages 6-9?

Does the subject of technology have a fixed number of teaching hours in your school?
Have you participated in some kind of in-service- training in technology?
Are you, according to the new rules, qualified to teach technology?

The questions from the students have a large impact on my technology teaching.

Are you teaching ages 1012 ?

The possibilities for inspiration and excursions in the nearby area have a large impact on my technology teaching.

Other teaching methods, such as

My colleagues have a large impact on my technology teaching.

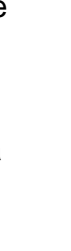

Are you teaching ages 13$15 ?$

What year did you graduate?

Are you a man or a woman?

\footnotetext{
Factor 1 - Technology education is important

- Technology is an important subject

- It is a good thing that technology is compulsory throughout school

Knowledge of technology is generally important for the students and their future

The subject of technology will have increased importance in the future
}

Factor 2 - Conditions are favorable for technology education

- At my school, we have plenty of good teaching material for technology education

- How satisfied are you overall with the way technology education is managed in your school?

- At my school there are well-established work fields in technology

- I get sufficient time for developing my teaching

. The management of my school wants to develop the subject of technology

Factor 3 - Curriculum is in focus for technology education

- I think the curriculum core content is a good starting point for teaching

- The knowledge requirements are clear

- The core content of the curriculum (is important on how I achieve technology education)

Factor 4 - Confidence, interest and knowledge of the teacher is high

- I feel confident in teaching technology

- I have the necessary training to conduct good technology education

I am passionate about the subject of technology

- My own interest/knowledge of various technology fields (is important on how I achieve technology education)

Figure 3. The four factors. 


\section{Results}

\section{Factor Analysis}

Exploratory factor analysis revealed that the underlying structure of the teachers' responses to the attitude items is best described by a four-factor model (Table 1) (Figure 3), explaining 63.9\% of the variance (Table 8). Each of the factors was interpreted by considering the included items. Thus, the first factor was distinguished by the importance of technology and the subject of technology, and will therefore be referred to as 'Technology education is important' in the following. The second factor was characterized by positive statements about how the teachers feel about the provisions and support for the subject in their school, and will be called 'Conditions are favorable for technology education'. All of the items in the third factor were about the curriculum, and this factor was therefore named 'Curriculum is in focus for technology education’. The last factor was named ‘Confidence, interest and knowledge of the teacher is high' since the items were about the teachers' own experience of, and comfort in, technology teaching. Cronbach’s Alpha values were greater than 0.70 for all factors, indicating that the instrument has adequate reliability for measuring the four attitude dimensions inherent in the identified factors (e.g. Field 2009).

Table 8. Names of the factors, variance explained, Reliability, Mean and Standard Deviation.

\begin{tabular}{lccccc}
\hline Component/Factor & Item & $\begin{array}{c}\text { \% of } \\
\text { variance } \\
\text { explained }\end{array}$ & $\begin{array}{c}\text { Reliability } \\
\text { (Cronbach's } \\
\text { alpha) }\end{array}$ & $\begin{array}{c}\text { Mean } \\
\text { (Range 1-6) }\end{array}$ & $\begin{array}{c}\text { Standard } \\
\text { deviation }\end{array}$ \\
\hline $\begin{array}{l}\text { 1. Technology education is } \\
\text { important }\end{array}$ & $2,3,5,7$ & 33.1 & 0.88 & 5.21 & 0.88 \\
$\begin{array}{l}\text { 2. Conditions are favorable } \\
\text { for technology education }\end{array}$ & $\begin{array}{c}1,4,10, \\
11,17\end{array}$ & 12.7 & 0.72 & 3.00 & 0.97 \\
$\begin{array}{l}\text { 3. Curriculum is in focus for } \\
\text { technology education }\end{array}$ & $9,13,14$ & 9.4 & 0.76 & 4.72 & 0.95 \\
$\begin{array}{l}\text { 4. Confidence, interest and } \\
\text { knowledge of the teacher is } \\
\text { high }\end{array}$ & 8,15, & 8.8 & 0.80 & & \\
\hline
\end{tabular}




\section{Cluster Analysis}

The three identified clusters (Table 3 and Figure 4) were interpreted in terms of the underlying attitude dimensions based on the factor values. In the following, each cluster is characterized and labeled.

'Positive' cluster ( $\mathrm{n}=419)$ : This cluster had relatively high values on all the four factors. Teachers in this cluster view technology education as very important (5.48 of 6). They perceive the conditions in their schools to be favorable, although not very good (3.52 of 6). They have a strong focus on the curriculum, and they feel secure in their teaching and their knowledge of the subject.

'Negative' cluster ( $\mathrm{n}=296)$ : This cluster had relatively low values on each of the four factors, implying that teachers in this cluster tend to view technology education as less important, and school conditions as less favorable, and tend to focus less on the curriculum than teachers in the positive cluster. In addition, they tend to assess themselves as less secure in the subject (education and interest) than teachers in the positive cluster.

'Mixed' cluster ( $\mathrm{n}=423$ ): This cluster displayed factor values that were relatively high on two of the factors (factors 1 and 3) and relatively low on two (factors 2 and 4). Hence, teachers in this cluster find technology education to be important and have a strong focus on the curriculum. They do however, also tend to experience the conditions in their schools as worse compared to teachers in the positive cluster and they feel less educated and secure in their subject. 


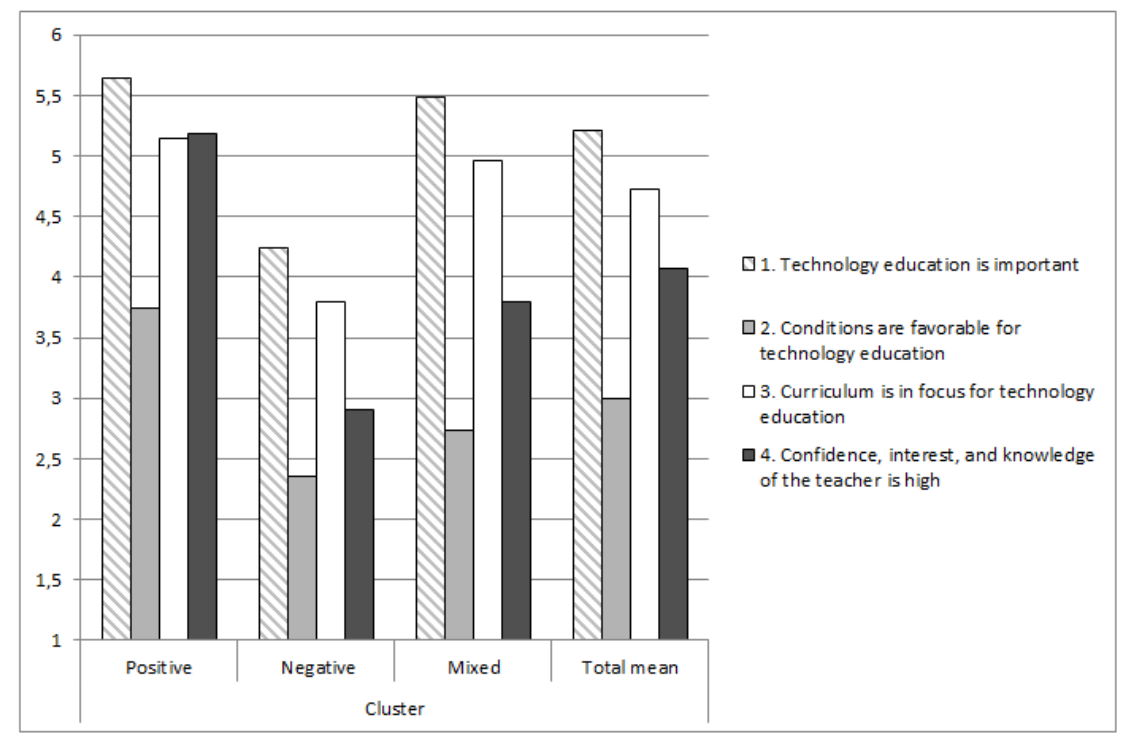

Figure 4. Cluster means and total means for each of the four factors.

\section{Multinomial logistic regression}

The full model, containing all the predictors, was statistically significant. The model classified $58.5 \%$ of the cases correctly. There was a significant relationship between cluster membership and the predictors in the model $\left(x^{2}=402.63, d f=40, \mathrm{p}<0.001\right)$. Pearson and Deviance tests of Goodness-of-fit indicated a good fit $(\mathrm{p}>0.05)$. The results are displayed in Table 9 - Table 11, where significant Odds Ratios are indicated in bold. The results can be described as follows, with the Positive cluster as the reference group:

\section{Variables of the teachers' backgrounds}

The result (Table 9) indicates that the variable with the highest contribution in this category was qualification. Teachers qualified in technology were about five times more likely to be in the Positive cluster than in one of the others. Gender did not have a significant effect on the likelihood of being in the Negative cluster, but the odds for a man to be in the Mixed cluster were half as large as for a woman. The only significant result with respect to students' ages was that teachers of students aged 10-12 years were about twice as likely to be in the 
Negative cluster as in the Positive, compared to teachers who taught ages 13-15. Teachers who had participated in some kind of in-service-training in technology were less likely to end up in either the Negative cluster (with an odds ratio of 0.28 ) or the Mixed cluster (with an odds ratio of 0.49). There were no significant differences in cluster-belonging when it came to graduating year, except for teachers who graduated in 1960-1979. They were about twice as likely to end up in the Negative cluster as the Positive, compared to those who graduated in 2000-2011.

Table 9. Results of a Multinomial Logistic Regression with respect to predictor variables related to the teachers' backgrounds.

\begin{tabular}{|c|c|c|c|c|c|c|c|c|}
\hline \multirow[b]{2}{*}{ Predictors (reference category) } & \multirow[b]{2}{*}{$\mathrm{B}(\mathrm{SE})$} & \multicolumn{3}{|c|}{$\begin{array}{l}\text { 95\% Confidence Interval } \\
\text { for Exp (B) }\end{array}$} & \multirow[b]{2}{*}{ B (SE) } & \multicolumn{3}{|c|}{$\begin{array}{l}\text { 95\% Confidence Interval } \\
\text { for } \operatorname{Exp}(\mathrm{B})\end{array}$} \\
\hline & & Lower & $\begin{array}{l}\text { Odds } \\
\text { Ratio }\end{array}$ & Upper & & Lower & $\begin{array}{l}\text { Odds } \\
\text { Ratio }\end{array}$ & Upper \\
\hline Intercept & $4.90(0.69)$ & & *** & & $3.37(0.58)$ & & 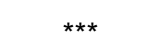 & \\
\hline \multicolumn{9}{|l|}{ Variables of the teachers' backgrounds } \\
\hline Man (Woman) & $-0.42(0.27)$ & 0.39 & 0.66 (ns) & 1.10 & $-0.69(0.23)$ & 0.32 & $0.50 * *$ & 0.78 \\
\hline Qualified to teach technology (not qualified) & $-1.82(0.22)$ & 0.11 & $0.16 * * *$ & 0.25 & $-1.51(0.18)$ & 0.15 & $0.22^{\star * *}$ & 0.32 \\
\hline Teaching age 6-9 (Teaching ages 13-15) & $0.73(0.46)$ & 0.84 & $2.01(\mathrm{~ns})$ & 5.01 & $0.04(0.36)$ & 0.52 & 1.04 (ns) & 2.10 \\
\hline $\begin{array}{l}\text { Teaching age } 10-12 \text { (Teaching ages } 13-15 \text { ) } \\
\text { Teaching among several ages (Teaching } \\
\text { ages } 13-15 \text { ) }\end{array}$ & $\begin{array}{l}0.76(0.38) \\
0.39(0.38)\end{array}$ & $\begin{array}{l}1.02 \\
0.70\end{array}$ & $1.47(\mathrm{~ns})$ & $\begin{array}{l}4.51 \\
3.09\end{array}$ & $\begin{array}{l}0.06(0.29) \\
-0.48(0.29)\end{array}$ & 0.60 & $0.62(\mathrm{~ns})$ & $\begin{array}{l}1.90 \\
1.09\end{array}$ \\
\hline $\begin{array}{l}\text { Has participated in some kind of in-service- } \\
\text { training in technology (not participated) }\end{array}$ & $-1.29(0.26)$ & 0.17 & $0.28^{* * *}$ & 0.46 & $-0.71(0.23)$ & 0.31 & $0.49^{* *}$ & 0.77 \\
\hline $\begin{array}{l}\text { Graduation year 1960-1979 (Graduation year } \\
\text { 2000-2011) }\end{array}$ & $0.69(0.30)$ & 1.10 & $1.99 *$ & 3.60 & $0.27(0.26)$ & 0.78 & $0.31(\mathrm{~ns})$ & 2.20 \\
\hline $\begin{array}{l}\text { Graduation year 1980-1989 (Graduation year } \\
\text { 2000-2011) }\end{array}$ & $0.24(0.32)$ & 0.68 & $1.28(\mathrm{~ns})$ & 2.41 & $0.18(0.27)$ & 0.71 & $1.20(\mathrm{~ns})$ & 2.04 \\
\hline $\begin{array}{l}\text { Graduation year 1990-1999 (Graduation year } \\
2000-2011 \text { ) }\end{array}$ & $0.43(0.26)$ & 0.92 & 1.54 (ns) & 2.57 & $0.38(0.22)$ & 1.46 & $1.46(\mathrm{~ns})$ & 2.23 \\
\hline
\end{tabular}

Note: 'The Positive' is the reference group ${ }^{*} P<0.05$, ${ }^{* *} P<0.01$, ${ }^{* \star *} P<0.001$.

\section{Variables of the school context}

This part of the results is presented in table 10. Teachers in schools without a fixed number of teaching hours for the subject of technology had approximately double the odds of being in the Negative cluster (with an odds ratio of 2.13), or the Mixed cluster (with an odds ratio of 
1.84) compared to the teachers in schools with a fixed number of hours. The teachers who did not know if there was a fixed number of teaching hours in their school had an even higher chance (with an odds ratio of 4.21) of being in the Negative cluster. The odds ratio of being in the Mixed cluster was 2.48. Teachers in schools with an overall planning based on the curriculum Lgr 11 (introduced 2011) for the subject were about three times less likely to be in the Negative cluster and about 2.5 times less likely to be in the Mixed cluster. The other school context predictor variables did not contribute significantly to cluster belonging in this model.

Table 10. Results of a Multinomial Logistic Regression with respect to predictor variables related to the school context.

\begin{tabular}{|c|c|c|c|c|c|c|c|c|}
\hline \multirow[b]{2}{*}{ Predictors (reference category) } & The Ne & $\begin{array}{l}\text { gative v } \\
95 \%\end{array}$ & $\begin{array}{l}\text { The Pos } \\
\text { Confidence } \\
\text { for Exp (B }\end{array}$ & $\begin{array}{l}\text { itive } \\
\text { Interval }\end{array}$ & The I & $\begin{array}{r}\text { Mixed vs. } \\
95 \%\end{array}$ & $\begin{array}{l}\text { The Positi } \\
\text { Confidence } \\
\text { for Exp (B) }\end{array}$ & $\begin{array}{l}\text { ive } \\
\text { Interval } \\
\text { 3) }\end{array}$ \\
\hline & $\mathrm{B}(\mathrm{SE})$ & Lower & $\begin{array}{l}\text { Odds } \\
\text { Ratio }\end{array}$ & Upper & B (SE) & Lower & $\begin{array}{l}\text { Odds } \\
\text { Ratio }\end{array}$ & Upper \\
\hline Intercept & $4.90(0.69)$ & & *** & & $3.37(0.58)$ & & $\star \star \star *$ & \\
\hline $\begin{array}{l}\text { Variables of the school context } \\
\text { The subject of technology does not have a } \\
\text { fixed number of teaching hours in my school } \\
\text { (Technology has a fixed number of teaching } \\
\text { hours) } \\
\text { I don't know if the subject of technology has a } \\
\text { fixed number of teaching hours in my school } \\
\text { (Technology has a fixed number of teaching } \\
\text { hours) }\end{array}$ & $0.76(0.26)$ & 1.29 & $2.13^{* *}$ & 3.51 & $0.61(0.21)$ & 1.21 & $1.84^{* *}$ & 2.78 \\
\hline $\begin{array}{l}\text { Technology is integrated with other subjects } \\
\text { (Technology is a subject in its own right) } \\
\text { Technology teaching is taught in theme-days, } \\
\text { at science centres, at museums or other } \\
\text { alternatives (Technology is a subject in its } \\
\text { own right) } \\
\text { The subject of technology has an overall } \\
\text { planning based on the new curriculum Lgr } 11 \\
\text { in my school (The subject of technology does } \\
\text { not have an overall planning based on the } \\
\text { new curriculum Lgr11) }\end{array}$ & $0.51(0.34)$ & 0.95 & 1.66 (ns) & 3.55 & $0.09(0.34)$ & 0.56 & 1.09 (ns) & 1.93 \\
\hline
\end{tabular}

Notes: 'The Positive' is the reference group ${ }^{*} \mathrm{P}<0.05$, ${ }^{* *} \mathrm{P}<0.01,{ }^{* \star *} \mathrm{P}<0.001$. 
Variables of teaching methods and materials

These variables were assessed using a Likert-type scale with a response range from 1 to 6 , and the odds ratios reported in Table 11 indicates the change in odds for each successive step along the corresponding Likert scale. The odds for a teacher to be in the Negative cluster decreased with increasing responses to the two variables Other teaching methods, like contests, have large impact on my technology teaching (with an odds ratio of 0.69 ) and The possibilities for inspiration and excursions in the nearby area have large impact on my technology teaching (with an odds ratio of 0.43). Conversely, the odds increased with increasing response values for the two variables The methodology of the educational material has a large impact on my technology teaching (with an odds ratio of 1.21) and My colleagues have a large impact on my technology teaching (with an odds ratio of 1.29). The probability of classifying a teacher as belonging to both the Negative cluster (with an odds ratio of 0.43 ) and the Mixed cluster (with an odds ratio of 0.71 ) increased for increasing values of responses to the variable The questions from the students have a large impact on my technology teaching.

Table 11. Results of a Multinomial Logistic Regression with respect to predictor variables related to variables of teaching methods and materials.

\begin{tabular}{|c|c|c|c|c|c|c|c|c|}
\hline \multirow[b]{2}{*}{ Predictors } & \multirow[b]{2}{*}{$\mathrm{B}(\mathrm{SE})$} & \multicolumn{3}{|c|}{$\begin{array}{l}\text { 95\% Confidence Interval } \\
\text { for } \operatorname{Exp}(\mathrm{B})\end{array}$} & \multirow[b]{2}{*}{$B(S E)$} & \multicolumn{3}{|c|}{$\begin{array}{l}\text { 95\% Confidence Interval } \\
\text { for } \operatorname{Exp}(\mathrm{B})\end{array}$} \\
\hline & & Lower & $\begin{array}{l}\text { Odds } \\
\text { Ratio }\end{array}$ & Upper & & Lower & $\begin{array}{l}\text { Odds } \\
\text { Ratio }\end{array}$ & Upper \\
\hline Intercept & $4.90(0.69)$ & & *** & & $3.37(0.58)$ & & 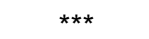 & \\
\hline $\begin{array}{l}\text { Variables of teaching methods and } \\
\text { materials }\end{array}$ & & & & & & & & \\
\hline $\begin{array}{l}\text { The methodology of the educational material } \\
\text { has a large impact on my technology teaching } \\
\text { Other teaching methods, like contests, have a }\end{array}$ & $0.19(0.08)$ & 1.05 & $1.21^{*}$ & 1.40 & $0.03(0.06)$ & 0.91 & 1.03 (ns) & 1.17 \\
\hline large impact on my technology teaching & $-0.38(0.98)$ & 0.57 & $0.69 * * *$ & 0.83 & $-0.10(0.08)$ & 0.78 & $0.91(n s)$ & 1.07 \\
\hline $\begin{array}{l}\text { My colleagues have a large impact on my } \\
\text { technology teaching }\end{array}$ & $0.26(0.09)$ & 1.08 & $1.29 * *$ & 4.54 & $0.13(0.07)$ & 0.99 & 1.14 (ns) & 1.31 \\
\hline $\begin{array}{l}\text { The questions from the students have a large } \\
\text { impact on my technology teaching }\end{array}$ & $-0.84(0.12)$ & 0.34 & $0.43^{\star \star \star}$ & 0.54 & $-0.34(0.10)$ & 0.59 & $0.71^{\star * *}$ & 0.86 \\
\hline $\begin{array}{l}\text { The possibilities for inspiration and excursions } \\
\text { in the nearby area have a large impact on my }\end{array}$ & $-0.04(0.12)$ & 0.04 & & & $-0.34(0.10)$ & 0.05 & 0.11 & 0.00 \\
\hline technology teaching & $-0.20(0.09)$ & 0.68 & $0.82^{*}$ & 0.98 & $-0.15(0.08)$ & 0.74 & $0.86(\mathrm{~ns})$ & 1.00 \\
\hline
\end{tabular}

Notes: 'The Positive' is the reference group ${ }^{*} \mathrm{P}<0.05$, ${ }^{\star \star} \mathrm{P}<0.01,{ }^{\star \star *} \mathrm{P}<0.001$. 


\section{Discussion}

The results of the analysis reflect the complexity of teaching and education, with no single factor emerging as the most important in relation to teachers' attitudes. The findings indicate a range of different attitudes among the teachers and a number of factors may have an effect on the teachers' attitudes to their subject and its teaching. In the following, the results are discussed in relation to each of the two research questions that guided the study.

\section{What are Swedish technology teachers' attitudes to the subject of technology and its teaching?}

The answer to the first research question is informed by the results from the factor analysis and the cluster analysis. Exploratory factor analysis revealed four distinct attitude dimensions with different characteristics among the questionnaire items. Furthermore, the cluster analysis indicated differences between the teachers with respect to the four attitude dimensions. Given that 'cluster analysis will always create clusters, regardless of the actual existence of any structure' (Hair et al. 2010, 482), the validity of the discerned clusters resides in their conceptual meaningfulness. In this regard, the emerging picture of teacher attitudes is comparable to other studies, including a recent report from the Swedish Schools Inspectorate (Skolinspektionen 2014).

We interpret the first factor, 'Technology education is important', to correspond to an attitude dimension related to 'cognitive beliefs' in the theoretical model (van AalderenSmeets, Walma van der Molen, and Asma 2012). In general, it appears that the teachers in this study consider technology to be important, not least in the Positive cluster. Headmasters and teachers in general in Sweden have been shown to regard technology as a low status subject (Nordlander 2011; Skolinspektionen 2014), and a low status has also been identified as a weakness of technology education internationally (Jones, Buntting, and de Vries 2013). Nevertheless, the findings resonate with other studies, where the technology teachers 
themselves find the subject to be important, despite the fact that the subject generally seems to have a low status (e.g. Almutairi 2009).

The second and the third factor may both be interpreted as aspects of the 'perceived control' component in the three-part attitude model employed in this study (van AalderenSmeets, Walma van der Molen, and Asma 2012). The relatively low scores on the factor 'Conditions are favourable for technology education' indicated that the teachers, in particular those in the Negative and the Mixed clusters, were dissatisfied with the conditions in their school. This finding confirms previous reports from Sweden (Skolinspektionen 2014) and New Zealand, where a lack of equipment (Jones, Harlow, and Cowie 2004) and insufficient funding (Almutairi 2009) are two main areas of experienced difficulties.

When it comes to the other factor related to perceived control, 'Curriculum is in focus for technology education', the mean is rather high. This could indicate that the teachers believe that they are well aware of the curriculum and think that they follow it. According to the Swedish Schools Inspectorate (Skolinspektionen 2014), however, teachers follow the curriculum, but technology education is often taught at too low level, for example, primary level to students in lower secondary education.

The fourth factor, 'Confidence, interest and knowledge of the teacher is high' can be interpreted as a reflection of the 'affective states’ attitude dimension (van Aalderen-Smeets, Walma van der Molen, and Asma 2012). This factor displayed the widest variation in the present study, largely because of the attitude gap between the Positive and the Negative clusters. This might indicate that this is the most interesting area for further investigation, given that a lack of confidence in technology teaching is a problem. According to Holroyd and Harlen (1996), a lack of confidence and understanding affects how the teachers teach. They argue that teachers find strategies to deal with their lack of confidence and those strategies probably do not end up in the best learning opportunities for the students. If we put 
this argumentation in a Swedish context, it might explain some of the findings in this study. A possible explanation, which should be further examined, is that teachers stay in their comfort zone when they teach, and that may lead to technology teaching at a lower level or with more focus on other subjects (Holroyd and Harlen 1996). It may also lead to teachers doing what they were taught in their own education or in their own in-service training.

Given that the questionnaire has not been validated before, the reported exploratory factor analysis provides initial indications of construct validity. In particular, the factors conform to the attitude model (van Aalderen-Smeets, Walma van der Molen, and Asma 2012) that was used as a theoretical framework for the study. Prior to this, face validity of the instrument had been ascertained by analyzing the individual items in the questionnaire and finding the formulations of the statements to plausibly require assessments based on attitudes toward technology and its teaching to be answered.

\section{What are the possible explanations for their different attitudes?}

Possible explanations can be suggested based on the results of the Multinomial Logistic Regression analysis. Several of the tested variables were found to have an effect as predictors for cluster belonging. The predictors with the greatest effect are found among the variables concerned with the teachers' background and those concerned with the school context.

Qualification to teach technology and in-service training were both found to be important predictors for cluster membership. In particular, teachers with qualification to teach technology are very likely to be in the positive cluster. This result may not be surprising given that 'one of the key factors influencing the development of technology education as a school subject is the education and professional development of teachers' (Jones, Buntting, and de Vries 2013, 202). The importance of well-educated technology teachers has been pointed out by many researchers (Hartell, Gumaelius, and Svärdh 2015; Gumaelius, Hartell, 
and Svärdh 2013; Mattsson 2005). Teachers’ pre-service and in-service education is among the background factors that affect technology teachers' teaching (Bjurulf 2008; Jones and Carr 1992). In addition to this, the results from the present study indicate that teachers’ attitudes to their subject may also be linked to educational factors such as qualification to teach technology and in-service training. In the present study, it is not possible to test whether professional development actually has a positive effect on the attitudes, or if teachers with positive attitudes for example might be more likely to work toward qualification. However, previous research has associated in-service training with more favorable attitudes toward technology teaching (Jones and Carr 1992, 238). Thus, while the cross-sectional nature of the present study does not account for causal relations, the findings nevertheless support a tentative interpretation of a beneficial effect on attitudes from teacher development initiatives such as in-service training and qualification.

Technology is one of the subjects with the fewest qualified teachers in the Swedish school system (Skolverket 2014), and calls to alleviate the lack of teachers with the desirable qualifications to teach technology have been raised for a long time (Elgström and Riis 1990). The potential connection between professional development and teachers' attitudes further emphasize that the situation may be problematic. Teachers with a positive attitude to the subject of technology are likely to communicate this attitude and the importance of the subject to their students, which could have various positive effects on the students.

Gender issues have garnered much interest in the technology education research literature, in particular with regard to potential links between gender and interest in technology (cf. Svenningson, Hultén, and Hallström 2015; Ardies, De Maeyer, and Gijbels 2015). However, gender differences regarding teachers have not been investigated to the same extent. The present study found gender to be a predictor for being in the Mixed cluster, with a lower probability of being in this cluster for men than women. Given that the Mixed 
cluster is characterized in part by a low confidence in their profession, the findings indicate that the women may be more likely to feel insecure than the men. The reason for this potential difference would be a very interesting issue to follow up. Similar findings have been obtained in Scotland, but in that case it was a more widespread phenomenon because 'men were more confident than women about almost everything directly to do with science and technology teaching' (Holroyd and Harlen 1996).

There is a lack of research in the technology education literature regarding the influence of variables of the school context. Results from the present study indicate that having a fixed number of teaching hours for technology is a strong predictor for cluster belonging. In particular, teachers who do not know whether or not their school has a fixed number of hours for technology are very likely to be in the Negative cluster. A lack of awareness among teachers regarding the subject's number of teaching hours might indicate that the subject is not prioritized in that school. Conversely, having an overall plan for the subject is positive, since lacking an overall plan increases the likelihood of being in the Negative cluster.

\section{Limitations}

The main limitation of this study is the response rate (34\%), which warrants caution in generalizing the observed attitude distribution to the entire population of Swedish technology teachers. In particular, it is likely that teachers with negative attitudes to the subject of technology were less likely to respond than teachers with positive attitudes. However, the response rate is well within the typical ranges reported in the literature for web-based surveys (e.g. Shih and Fan 2009; Kennedy and Archambault 2012), and should thus be acceptable for the statistical procedures performed and the conclusions regarding predictors. A further limitation was the limited range of different attitude dimensions that can be discerned through 
a questionnaire. Although the identified factors represent important attitude dimensions, there may also be other attitude dimensions that were not addressed by the items included in the instrument.

\section{Conclusions and implications}

The study has shown that technology teachers' attitudes towards their subject and its teaching as revealed by a questionnaire are structured along dimensions that conform to an established attitude model (van Aalderen-Smeets, Walma van der Molen, and Asma 2012), and that the teachers fall into distinct groups with respect to these attitudes. The results further contribute to technology education research by identifying important variables among teachers’ backgrounds, school contexts and teaching methods and materials that may predict attitudes. Hence, these predictors could inform the design of professional development interventions and policies intended to improve technology education while also supporting positive attitudes among teachers. In this regard, the results indicate that efforts to increase the number of qualified technology teachers and providing in-service education may be beneficial for teachers' attitudes. In addition, ensuring a sufficient and formally established number of teaching hours for the technology subject are possible actions that could support positive attitudes among teachers, and, in turn, an improved learning experience among pupils. Future research could delve deeper into these teacher attitudes by performing studies with a qualitative design to get a deeper understanding of personal and other factors influencing teacher attitudes. 


\section{References}

van Aalderen-Smeets, Sandra I., Juliette H. Walma van der Molen, and Lieke J. F. Asma. 2012. "Primary Teachers' Attitudes toward Science: A New Theoretical Framework.” Science Education 96 (1):158-82.

van Aalderen-Smeets, S., and J. Walma van der Molen. 2013. "Measuring Primary Teachers' Attitudes Toward Teaching Science: Development of the Dimensions of Attitude Toward Science (DAS) Instrument.” International Journal of Science Education 35 (4):577-600.

Almutairi, Abbad. 2009. “Teachers' perceptions of technology and technology education, years 7 to 10.” Thesis, Auckland University of Technology.

Ardies, J., S. De Maeyer, and D. Gijbels. 2015. “A longitudinal study on boys' and girls' career aspirations and interest in technology.” Research in Science and Technological Education 33 (3): 366-86.

Beavers, A. S., J. W. Lounsbury, J. K. Richards, S. W. Huck, G. J. Skolits, and S. L. Esquivel. 2013. "Practical considerations for using exploratory factor analysis in educational research.” Practical Assessment, Research and Evaluation 18 (6):1-13.

Bjurulf, Veronica. 2008. Teknikämnets gestaltningar: en studie av lärares arbete med skolämnet teknik, Karlstad University studies: 2008:29 [Embodying Technology Education: A Study of Teachers' Work with the Subject Technology]. Karlstad: Estetisk-filosofiska fakulteten, Pedagogiskt arbete, Karlstads universitet.

Clatworthy, J., D. Buick, M. Hankins, J. Weinman, and R. Horne. 2005. “The Use and Reporting of Cluster Analysis in Health Psychology.” British Journal Of Health Psychology 10 (3):329-58.

Dziuban, C. D., and E. C. Shirkey. 1974. "When is a correlation matrix appropriate for factor analysis? Some decision rules.” Psychological Bulletin 81 (6):358-61.

Elgström, Ole, and Ulla Riis. 1990. Läroplansprocesser och förhandlingsdynamik : exemplet obligatorisk teknik i grundskola [Curriculum Processes and the Dynamics of Negotiation: the Example of Obligatory Technology in Compulsory Education]. Linköping University.

Field, Andy. 2009. Discovering statistics using SPSS: (and sex and drugs and rock ' $n$ ' roll). 3d ed: London: SAGE.

Gumaelius, Lena , Eva Hartell, and Joakim Svärdh. 2013. “Teachers’ views regarding assessment in technology education.” In Technology Education for the Future: A Play on Sustainability, edited by P John Williams and Dilani Gedera, 196-205. Waikato: University of Waikato.

Hair, Joseph F., William C. Black, Barry J. Babin, and Rolph E. Anderson. 2010. Multivariate data analysis : a global perspective. 7th ed. Upper Saddle River, N.J.: Pearson Education

Hartell, Eva, Lena Gumaelius, and Joakim Svärdh. 2015. “Investigating technology teachers' self-efficacy on assessment.” International Journal of Technology \& Design Education 25 (3):321-37.

Henson, Robin K., and J. Kyle Roberts. 2006. "Use of Exploratory Factor Analysis in Published Research: Common Errors and Some Comment on Improved Practice.” Educational and Psychological Measurement 66 (3):393-416.

Holroyd, Colin, and Wynne Harlen. 1996. "Primary teachers' confidence about teaching science and technology.” Research papers in education 11 (3):323-35.

Jones, Alister, Cathy Buntting, and Marc J. de Vries. 2013. "The Developing Field of Technology Education: A Review to Look Forward.” International Journal of Technology and Design Education 23 (2):191-212. 
Jones, Alister, and Malcolm Carr. 1992. "Teacher's Perceptions of Technology Education: Implications for Curriculum Innovation.” Research in Science Education 22 (1):2309.

Jones, Alister, Ann Harlow, and Bronwen Cowie. 2004. "New Zealand Teachers' Experiences in Implementing the Technology Curriculum.” International Journal of Technology and Design Education 14 (2):101-19.

Kennedy, Kathryn, and Leanna Archambault. 2012. "Offering Preservice Teachers Field Experiences in K-12 Online Learning.” Journal of Teacher Education 63 (3):185.

Mattsson, Gunilla. 2005. ”Lärares teknikdidaktiska kompetens och dess betydelse för elevers teknikintresse [Teachers' Educational Competence in Technology and its Significance for Pupils'Interest in Technology].” Nordina 01 (01):31-42.

Mooi, Erik, and Marko Sarstedt. 2011. A concise guide to market research. Berlin: Springer. Nordlander, Edvard. 2011. "Vad tycker tekniklärarna? [What do Technology Teachers Think?]” In Teknikutbildning för framtiden [Technology Education for the Future], edited by Sven Ove Hansson, Edvard Nordlander and Inga-Britt Skogh, 90-102. Stockholm: Liber AB.

O'connor, Brian P. 2000. "SPSS and SAS programs for determining the number of components using parallel analysis and Velicer's MAP test.” Behavior research methods, instruments, \& computers 32 (3):396-402.

Osborne, Jonathan, Shirley Simon, and Sue Collins. 2003. "Attitudes towards Science: A Review of the Literature and Its Implications.” International Journal of Science Education 25 (9):1049-79.

Pett, Majorie A., Nancy R. Lackey, and John J. Sullivan. 2003. Making Sense of Factor Analysis. Thousand Oaks: SAGE Publications.

Rohaan, E. J., R. Taconis, and W. M. G. Jochems. 2012. “Analysing teacher knowledge for technology education in primary schools.” International Journal of Technology and Design Education 22 (3):271-80.

Shih, Tse-Hua, and Xitao Fan. 2009. "Comparing response rates in e-mail and paper surveys: A meta-analysis.” Educational Research Review 4 (1):26-40.

Skolinspektionen. 2014. "Teknik - gör det osynliga synligt. Om kvaliteten i grundskolans teknikundervisning [Technology - make the invisible visible. On the quality of compulsory schooltechnology education].” Stockholm.

Skolverket. 2011. Curriculum for the compulsory school, preeschool class and the recreation centre Stockholm: Ordförrådet AB.

Skolverket. 2013. ”Attityder till skolan 2012 [Attitudes to the school, 2012].” Stockholm: Fritzes.

Skolverket. 2014. "Redovisning av uppdrag om hur stor del av undervisningen som bedrivs av behöriga lärare.” 2014-09-25. Accessed 2015-08-18. http://www.skolverket.se/publikationer?id=3312.

Skolverket. 2016. "SiriS statistik avseende grundskolan” Acessed 2016-12-02. https://siris.skolverket.se/siris/f?p=SIRIS:36:0::NO:::

Svenningson, Johan, Magnus Hultén, and Jonas Hallström. 2015. “Swedish Students’ View on Technology: Results from a pilot study using an adaptation of the PATT-SQ questionnaire.” In PATT 29 Plurality and Complementarity of Approaches in Design \& Technology Education, edited by Marjolaine Chatoney, 397-403. Marseille: Presses Universitaires de Provence.

Tabachnick, Barbara G., and Linda S. Fidell. 2014. Using multivariate statistics 6th ed. New York: Harper Collins College Publishers.

Teknikföretagen. 2012. Teknikämnet i träda; teknikföretagens och CETIS rapport om teknikundervisningen i grundskolan [Technology Education in Repose: The 
Teknikföretagen and CETIS Report on Technology Education in Compulsory School]. Stockholm.

de Vries, Marc J. 1991. "What Do Students in Dutch Technology Teacher Programmes Think of Their Subject?” Research in Science and Technological Education 9 (2):173-179. 